\title{
PHYSICAL-CHEMICAL PARAMETERS IN RELATION TO FISH ASSEMBLAGES IN THE EAST COAST OF PENINSULAR MALAYSIA
}

\author{
SITI TAFZIMERIAM SHEIKH ABDUL KADIR ${ }^{1,2^{*}}$, NORATIKAH AB. MANAF ${ }^{1}$, AHMAD NAZILA ALI ${ }^{1}$, \\ NUR FATIHA CHE WAIL, JOSEPH ANAK BIDAI ${ }^{1}$, HAZRUL AHMAD ${ }^{1}$, \\ CHE MOHD KAMARUL ANUAR CHE ABDULLAH ${ }^{1}$, MOHD NASIR MOHAMAD ${ }^{1}$, \\ MUHAMMAD FAHMI AHMAD ${ }^{3}$, AMIRRUDIN AHMAD ${ }^{3}$, ZAINUDIN BACHOK ${ }^{1}$, \\ HIROYUKI MOTOMURA ${ }^{4}$, MOHD LOKMAN HUSAIN ${ }^{1,2}$, MOHD AZMI AMBAK \\ and MAZLAN ABD GHAFFAR ${ }^{5}$
}

\author{
${ }^{1}$ South China Sea Repository \& Reference Center, Institute of Oceanography and Environment (INOS), \\ University Malaysia Terengganu, 21030, Kuala Terengganu, Terengganu, Malaysia \\ ${ }^{2}$ Mangrove Research Unit (MARU), Institute of Oceanography and Environment (INOS), \\ University Malaysia Terengganu, 21030, Kuala Terengganu, Terengganu, Malaysia \\ ${ }^{3}$ Faculty of Science and Marine Environment, University Malaysia Terengganu, \\ 21030 Kuala Nerus, Terengganu, Malaysia \\ ${ }^{4}$ The Kagoshima University Museum, 1-21-30 Korimoto, Kagoshima 890-0065, Japan \\ ${ }^{5}$ Office of Deputy Vice-Chancellor (Research and Innovation) (PNC), \\ University Malaysia Terengganu, 21030, Kuala Terengganu, Terengganu, Malaysia \\ *E-mail: sititafzil@umt.edu.my
}

Accepted 2 December 2020, Published online 25 December 2020

\begin{abstract}
The fish assemblage patterns are partially dependent on the environmental or anthropogenic changes which always affect the community. The objective of this study was to determine the spatial and temporal distribution pattern of fish assemblages due to physical-chemical in Setiu Wetlands. Fish samples were collected from June 2011 to July 2012 at three study sites using gill, trawl nets, and traps. The salinity and $\mathrm{pH}$ results were significantly different among sites and the temperature, $\mathrm{pH}$, and DO revealed significant differences among months. However, the regression obtained between the abundance of fishes and rainfall and the physical-chemical parameters were not-significant differences. The low and negative correlation values were suggested and believed to not be sensitive between fish abundance and physical-chemical parameters. Four water physicalchemical variables in explaining variation in certain some fish species composition and abundance during the rainy and dry season in Setiu Wetlands. Our study revealed that the anthropogenic activities might be giving an impact on the wetlands related to the mean value of the physical-chemical characteristic. More extensive research is needed for over longer periods whereas long term research for five to ten years data to better understand for fish assemblages in Setiu Wetland.
\end{abstract}

Key words: Physical-chemical parameters, dry and rainy season, fish abundance, South China Sea

\section{INTRODUCTION}

The estuarine area can be influenced due to wide fluctuating water levels in the water movement and physical-chemical factors (Kennish, 1990). The estuarine resident fishes have a great body tolerance to adapt to these extreme fluctuations. The dynamic in both spatial and temporal range of intra-annual environmental differences and short-term changes,

\footnotetext{
* To whom correspondence should be addressed.
}

such as those of the day/night cycle, can also affect the interactions between the distribution and abundance of fish assemblages (Hossain et al., 2012). Chemical changes in water quality in stream and river systems also change interspecific competition and predation among fish communities (Gillian et al., 1993).

The study was conducted in Setiu Wetlands that are complex areas covered with a variety kind of habitats and inter-relation between abiotic and biotic. Suratman et al. (2016) showed the surface 
physical water quality for the Setiu Wetland was highly influenced by anthropogenic activities and seasonal variation. However, this previous study was not related to the fish abundance in Setiu Wetlands. The previous studies were focused on different biological aspects of spatial and seasonal variability of selected surface water quality parameters in Setiu wetland. This study was designed to fulfill the gap of those previous studies. Therefore, this study was required to determine the spatial and temporal distribution pattern of fish assemblages due to physical-chemical in Setiu Wetlands.

\section{MATERIAL AND METHODS}

Three different locations were selected for study sites, i.e., Site 1 (Pulau Telaga Tujuh) up North, Site 2 (Pulau Che Him) in the middle, and Site 3 (Pulau Tok Haji) down South. Site 2 and Site 3 were situated between river mouths, i.e., about $1 \mathrm{~km}$ and $5 \mathrm{~km}$ from the river mouth, respectively. The physical-chemical parameters (temperature, salinity, $\mathrm{pH}$ and dissolved oxygen) were measured monthly in-situ using multiparameter (YSI 556 MPS Meter) with three replicate data at 3 different sites; 1) in the upper water column $(0.1 \mathrm{~m}$ below the water surface); 2) middle and, 3) in the lower water column (0.1 m upper from the bottom). Sampling was conducted from June 2011 to July 2012 and was covered both rainy and dry seasons. The sampling methods used by multifilament gill nets, trawls, and fish traps to catch all sizes of fishes. The multifilament gill nets and fish traps were fixed at the high tide level, left overnight, and collected fish on the morning of the next days. Bottom trawls were conducted at each site at the high tide level in 3 replicates with fifteen-minute tows. All the fishes were placed in zipper plastic bags and put on ice, and transported back to further biological investigation at the laboratory.

All fishes were counted and identified according to species using available taxonomic keys (Ambak et al., 2010; Carpenter \& Niem, 1999-2001; Matsunuma et al., 2011; Mohsin \& Ambak, 1983; 1996; Nakabo, 2002). The fishes were measured individually for Total Length (TL) and weight to the nearest $1 \mathrm{~mm}$ and $0.01 \mathrm{gm}$ respectively. The fishes were fixed in $10 \%$ formalin solution and preserved in $70 \%$ alcohol. Specimens of each species were deposited in the collections of the South China Sea Repository and Reference Centre (RRC), Institute of Oceanography and Environment (INOS), Universiti Malaysia Terengganu. A nonparametric (Kruskal-Wallis) test was performed to determine the differences in the physical-chemical parameters among the sampling sites and months. Spearman rank-order correlations
(Spearman R coefficient) and regression were calculated to study the structure between variables of physical-chemical parameters. For multivariate analysis, canonical correspondence analysis (CCA) was applied to look at the association between physical-chemical parameters and species abundance. The pre-treatment of the data was conducted in PRIMER 6 while CCA was in PAST 3.22 .

\section{RESULTS AND DISCUSSION}

In Setiu Wetlands, the differences in the spatial and temporal patterns of species between sites and months in relation to physical-chemical parameters require an explanation. The salinity and $\mathrm{pH}$ results were showed a significant difference between sites. The salinity $(p=0.01, p<0.05)$ showed a significant difference between sites as it is related to the tidal sea level rise where the water flows from the mouth of the rivers. The salinity ranged in this study was recorded between 7.1 and $35.4 \mathrm{ppt}$ is comparable with that of 12.0 to $33.5 \mathrm{ppt}$ study in Setiu Wetlands (Suratman et al., 2014). There was a significant increase in freshwater mixing in the Site 3 area low to a range of 7.1 to $32.1 \mathrm{ppt}$. The mix of both freshwaters flows from the south and tidal sea level rise resulted in the lowest salinity at Site 3 in September 2012. In terms of fish species, salinity was the most important variable in explaining variation in species composition in axis 2 (Figure 1). Most of the fishes were responded negatively with salinity. Epinephelus coioides, Lutjanus russellii, Toxotes jaculatrix, Yarica hyalosoma, and Dichotomyctere nigroviridis were the example of species that highly abundant during low salinity in June, July, September, and November of 2011 (Figure 1). The peripheral fishes move to low salinity and freshwater habitats to feeding and protection from marine predators (Flannery et al., 2002; Kadir et al., 2019). The marine species move to coastal shallow waters before reaching maturity, where they contribute to the coastal fisheries delay (Barletta-Bergan et al., 2002; Barletta \& Saint-Paul, 2010; Kadir et al., 2019).

Some species like Ambassis interrupta, Siganus guttatus, and Zenarchopterus dunckeri had a strong correlation with salinity which was associated with April, June, and July of 2012. This exposed that salinity affects fish distribution in certain site study areas. Site 2 showed the highest salinity that ranges from 16.3 to $35.4 \mathrm{ppt}$ between other sites. Site 2 near the estuarine mouth compared to Site 1 and Site 3. For overall fish species, Site 2 showed the highest number of individual fishes and species. Most estuarine fishes could tolerate salinity fluctuations, but their adaptability and distribution varied among 

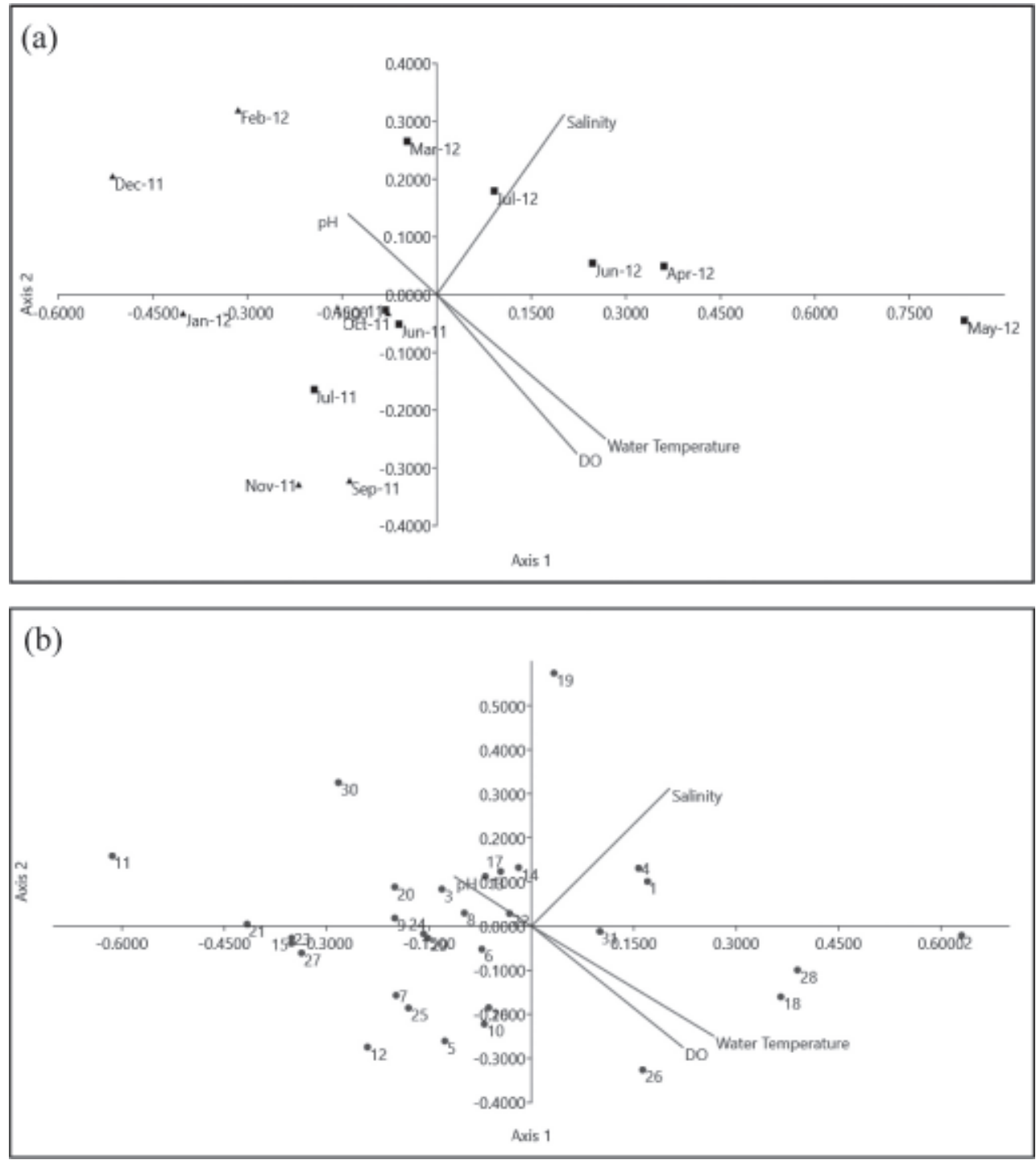

Fig. 1. Canonical correspondence analysis (CCA) ordination of 31 fish species abundance with major water physical-chemical properties, i.e., $\mathrm{pH}$, water temperature, salinity, dissolved oxygen (DO), in 14 mth sampling period. (a) optimal display of CCA in scaling type 1 for samples (sampling month) interpretation (b) optimal display of CCA using scaling type 2 to examine species correlation with environmental gradients. $1=$ Ambassis interrupta; $2=$ Nuchequula longicornis; 3 =Leiognathus equula; 4 = Siganus guttatus; 5 = Lutjanus russellii; $6=$ Yarica hyalosoma $; 7=$ Dichotomyctere nigroviridis; 8 = Ambassis kopsii; 9 = Strongylura strongylura $; 10=$ Lates calcarifer $; 11=$ Pseudorhombus arsius; 12 = Epinephelus coioides; $13=$ Chelonodontops patoca $; 14=$ Hexanematichthys sagor; 15 = Brachirus orientalis; 16 = Siganus javus; $17=$ Pelates quadrilineatus; $18=$ Arius maculatus $; 19=$ Zenarchopterus dunckeri; $20=$ Glossogobius aureus $; 21=$ Vespicula trachinoides; 22 = Allenbatrachus grunniens; $23=$ Psammogobius biocellatus; $24=$ Sillago sihama ; $25=$ Toxotes jaculatrix; $26=$ Triacanthus blochii $; 27=$ Gerres filamentosus $; 28=$ Pamadasys kaakan; $29=$ Gerres limbatus $; 30=$ Platycephalus indicus; $31=$ Brevitrygon walga .

species, depending on physiological tolerances, which may influence their distributions (Blaber, 1997). The average $\mathrm{pH}$ of seawater values ranged from 4.8 to 8.5. The range of $\mathrm{pH}$ in Setiu Wetlands showed 6.9 to 8.6 (Suratman et al., 2014) and 5.2 to 8.0 (Suratman et al., 2005). Consequently, the results were in a not good range as most organisms living in estuaries prefer a $\mathrm{pH}$ between 6.5 and
8.5. Thus Site 1 and Site 2 recorded relatively equal values where it is a slightly in average $\mathrm{pH}$ of seawater. In this study, the $\mathrm{pH}(p=0.0, p<0.01)$ showed a significant difference between sites. The $\mathrm{pH}$ in Site $2(8.0 \pm 0.7)$ was highest followed by Site $1(7.6 \pm 0.7)$ and the lowest at Site $3(6.9 \pm 0.9)$ (Table 1). The $\mathrm{pH}$ from Sites 3 low till ranged to $(4.8-8.5)$. 
Table 1. Average physical-chemical parameters \pm SD at different sites and months recorded from Setiu Wetlands from June 2011 to July 2012

\begin{tabular}{lcccc}
\hline Sites / Month & $\begin{array}{c}\text { Temperature }\left({ }^{\circ} \mathrm{C}\right) \\
\text { Mean } \pm \text { SD }\end{array}$ & $\begin{array}{c}\text { Salinity (ppt) } \\
\text { Mean } \pm \text { SD }\end{array}$ & $\begin{array}{c}\text { Dissolved oxygen (mg/L) } \\
\text { Mean } \pm \text { SD }\end{array}$ & $\begin{array}{c}\mathrm{pH} \\
\text { Mean } \pm \text { SD }\end{array}$ \\
\hline Overall mean & $30 \pm 1.3$ & $29.4 \pm 6.0$ & $6.9 \pm 2.8$ & $7.5 \pm 0.8$ \\
S1 & $30.2 \pm 1.2^{\mathrm{a}}$ & $30.0 \pm 9.9^{\mathrm{ab}}$ & $7.6 \pm 5.4^{\mathrm{a}}$ & $7.6 \pm 0.7^{\mathrm{a}}$ \\
S2 & $30.1 \pm 1.2^{\mathrm{a}}$ & $31.1 \pm 3.0^{\mathrm{a}}$ & $6.1 \pm 1.3^{\mathrm{a}}$ & $8.0 \pm 0.7^{\mathrm{a}}$ \\
S3 & $29.7 \pm 1.5^{\mathrm{a}}$ & $27.2 \pm 5.0^{\mathrm{b}}$ & $6.9 \pm 1.6^{\mathrm{a}}$ & $6.9 \pm 0.9^{\mathrm{b}}$ \\
Interactions & $\mathrm{NS}$ & $*$ & $\mathrm{NS}$ & $6.5 \pm 0.1$ \\
\hline June 2011 & $31.0 \pm 0.5$ & $25.1 \pm 3.4$ & $7.6 \pm 0.2$ & $7.8 \pm 0.2$ \\
July 2011 & $30.1 \pm 0.1$ & $26.7 \pm 4.3$ & $7.4 \pm 0.2$ & $8.5 \pm 0.03$ \\
August 2011 & $30.7 \pm 0.1$ & $28.3 \pm 1.8$ & $8.7 \pm 1.7$ & $7.3 \pm 0.2$ \\
September 2011 & $30.2 \pm 0.3$ & $23.3 \pm 5.4$ & $6.2 \pm 0.1$ & $7.4 \pm 0.4$ \\
October 2011 & $30.2 \pm 1.2$ & $19.2 \pm 9.1$ & $5.6 \pm 1.2$ & $7.0 \pm 0.8$ \\
November 2011 & $29.2 \pm 0.7$ & $22.1 \pm 5.3$ & $7.3 \pm 0.8$ & $7.3 \pm 0.2$ \\
December 2011 & $26.3 \pm 1.2$ & $22.1 \pm 5.2$ & $6.7 \pm 1.1$ & $7.4 \pm 0.7$ \\
January 2012 & $29.4 \pm 0.9$ & $22.6 \pm 5.3$ & $5.5 \pm 0.8$ & $7.5 \pm 0.5$ \\
February 2012 & $30.7 \pm 1.9$ & $27.1 \pm 7.1$ & $5.5 \pm 0.3$ & $7.6 \pm 0.3$ \\
March 2012 & $30.8 \pm 1.2$ & $24.2 \pm 8.9$ & $5.5 \pm 0.9$ & $7.6 \pm 1.0$ \\
April 2012 & $31.3 \pm 1.0$ & $26.3 \pm 7.9$ & $5.6 \pm 1.7$ & $7.1 \pm 1.7$ \\
May 2012 & $30.3 \pm 1.0$ & $28.3 \pm 7.4$ & $5.0 \pm 1.7$ & $7.2 \pm 1.3$ \\
June 2012 & $31.2 \pm 0.7$ & $29.3 \pm 6.7$ & $4.7 \pm 0.9$ & $7.3 \pm 0.7$ \\
July 2012 & $30.1 \pm 0.4$ & $29.3 \pm 7.0$ & $5.1 \pm 1.0$ & $* * *$ \\
Interactions & $* * *$ & $\mathrm{NS}$ & $*$ \\
\hline
\end{tabular}

Note: For each environmental variable, medians with the same letter superscript are not significantly different; NS - not significantly different. The median with the different letter is significant at ${ }^{*} p<0.05,{ }^{* *} p<0.01,{ }^{* * *} p<0.0001$.

However, the $\mathrm{pH}(p=0.0, p<0.0001)$ showed a significant difference between months. The $\mathrm{pH}$ values were recorded with variation, the highest in August $2011(8.5 \pm 0.03)$ (the late dry season) and the lowest in June $2011(6.5 \pm 0.1)$ (the late dry season) (Table 1). In April 2012, in the early dry season, the $\mathrm{pH}$ value was 4.6 and it was the lowest recorded in Site 3. In contrast by Suratman et al. (2016), revealed that during the wet season where low DO, low pH, and low TSS levels, but high BOD levels, were observed in the wetland whereas shown that the water quality was impacted mostly by aquaculture and agriculture. This study found that the dry season also brings a lot of acidic substances into the aquatic environment. Suratman et al. (2009) stated that the high $\mathrm{BOD}_{5}$ concentrations impacted the lower DO value and caused the increase of carbon dioxide and directly the decrease of $\mathrm{pH}$ values. The $\mathrm{pH}$ values in the aquatic ecosystem were influenced by carbon dioxide during the photosynthesis process, respiration, and decomposition (Riley \& Chester, 1971). Shukor et al. (2008) stated that the wastes may change $\mathrm{pH}$ values because those would increase photosynthesis in rivers. Estuarine fishes, especially larvae and juveniles are more susceptible to ammonia poisoning in waters of high salinity, low $\mathrm{pH}$, and high ammonia loading (Eddy, 2005), whereas a high acidic condition is detrimental to both the fish food organisms and fish (Alongi, 2002). This suggesting that the anthropogenic activities might be giving an impact on the wetlands related to the mean value of physical-chemical characteristics in this study.

In term of fish species, the results showed Pseudorhombus arsius, Glossogobius aureus, Platycephalus indicus and were some species that exhibit high correlation with water $\mathrm{pH}$ but negatively correlated with dissolved oxygen, temperature, and salinity (Figure 1). That indicated the $\mathrm{pH}$ influenced by some fish species distribution. Furthermore, the results on temperature, $\mathrm{pH}$, and DO reveal a significant difference between months and thus would influence that value range. While Arius maculatus, Triacanthus blochii, and Pamadasys kaakan were species that had a high correlation with dissolved oxygen, temperature, and salinity. These water physical-chemical properties and species were associated with post-monsoon weather in 2012 (Figure 1). The evidence is the post-monsoon change in water's physical-chemical properties and some fish composition in Setiu Wetlands. Furthermore, $P$. kaakan show a high correlation with temperature (Figure 1). Bagenal (1978) stated that temperature is an important external factor in the early life stages of fish because it has a direct influence on the timing of ontogenetic events. Temperature affects directly or indirectly other immunological parameters such as transparency, viscosity, dissolved gases, $\mathrm{pH}$, total 
dissolved solids, conductivity (Whitney, 1942). The fish assemblages can also be used as an indicator of habitat degradation whereas changes in fish assemblages may quantify disturbances that have occurred in the ecosystem (Othman, 2014).

The temperatures observed much variation within a month showed highest in April 2012 (31.3 $\pm 1.0^{\circ} \mathrm{C}$ ) in the early dry season and the lowest in December $2011\left(26.3 \pm 1.2^{\circ} \mathrm{C}\right)$ (the early rainy season) (Table 1). In this study, the value range of temperature was shown from August 2011 (the late dry season) with $30.6^{\circ} \mathrm{C}$ to March 2012 in the early dry season $\left(33.0^{\circ} \mathrm{C}\right)$ whereas pre-northeast monsoon season. In this study, the values of DO ranged between 3.3 and $10.9 \mathrm{mg} / \mathrm{L}$. The DO value dropped to $5.1-5.9 \mathrm{mg} / \mathrm{L}$ in February 2012 (the late rainy season). The lowest DO value between sites and month was $(3.7 \mathrm{mg} / \mathrm{L}$ ) in S2 (December 2012; the early rainy season). Whereas the DO content varied from 2.21 to $6.25 \mathrm{mg} / \mathrm{L}$ in Setiu Wetlands (Suratman et al., 2014); 3.2 to $5.1 \mathrm{~mL} / \mathrm{L}$ in mangroves of Goa (Fernandes \& Achuthankutty, 2010), and 5 to $6 \mathrm{mg} / \mathrm{L}$ in nearshore in the Gulf of Thailand (Sichum et al., 2013).

Furthermore, the regression obtained between the abundance of fishes and rainfall and the physical-chemical parameters were not significant. Results indicate a low and negative correlation (with a correlation coefficient of $-0.13,0.42,0.20$, $-0.06,-0.18$ ) between rainfall, temperature, salinity, $\mathrm{DO}, \mathrm{pH}$ values, and fish abundance respectively. As a whole, the correlation values suggested that fish abundance are not related to weather and physicalchemical parameters. However, the four water physical-chemical variables in explaining variation in certain some fish species composition and abundance during the dry and rainy season in Setiu.

\section{CONCLUSION}

In conclusion, the salinity and $\mathrm{pH}$ statistically showed a significant difference (KruskalWallis $\mathrm{H}$ test; $p<0.05$ ) between sites, and the temperature, $\mathrm{pH}$, and DO statistically showed a significant difference (KruskalWallis H test; $(p<0.0001)$ between months whereas would influence that value range. The evidence is the post-monsoon change in water's physical-chemical properties and some fish composition in Setiu Wetlands. This study might be that the anthropogenic activities give an impact on the wetlands related to the mean value of the physical-chemical characteristic. However, the regression obtained between the abundance of fishes and rainfall and the physical-chemical parameters were not significant. The results indicate a low and negative correlation (with a correlation coefficient of $-0.13,0.42,0.20,-0.06,-0.18)$ between rainfall, temperature, salinity, $\mathrm{DO}, \mathrm{pH}$ values, and fish abundance respectively. As a whole, the correlation values suggested that fish abundance is not related to weather and physical-chemical parameters and is believed not to be sensitive between those parameters. The different fish species were required in selecting spatial and temporal for recruitment and settlement in their life cycle. More extensive research is needed over longer periods whereas long-term research for five to ten years data to better understand for fish assemblages in Setiu Wetland.

\section{ACKNOWLEDGMENTS}

The authors would like to thank the management of Institute Oceanography and Environment (INOS), UMT for funding and for allowing us to use their facility and staff for assistance during the field trips and for collecting specimens. This study was partially supported by the Ministry of Higher Education, Malaysia under the Higher Institution Centre of Excellence (HICoE) Research Grant (Vote No. 66928).

\section{REFERENCES}

Alongi, D.M. 2002. Present state and future of the world's mangrove forests. Environmental Conservation, 29(3): 331-349.

Ambak, A.A., Mansor, M.I., Mohd Zaidi, Z. \& Mazlan, A.G. 2010. Fishes of Malaysia. Universiti Malaysia Terengganu, Terengganu.

Ara, R., Arshad, A., Musa, L., Amin, S.M.N. \& Kuppan, P. 2011. Environment and diversity of ichthyoplankton in the seagrass beds of Sungai Pulai Estuary, Johor, Peninsular Malaysia. Journal of Food, Agriculture, and Environment, 9: 733-738.

Bagenal, T.B. 1978. Aspects of Fish Fecundity. In: Ecology of Freshwater Fish Production. S.D. Gerking (Eds.). Blackwell Scientific, Oxford, England. pp. 75-95.

Barletta-Bergan, A., Barletta, M. \& Saint-Paul, U. 2002. Structure and seasonal dynamics of larval fish in the Caete River in north Brazil. Estuarine, Coastal and Shelf Science, 54: 193206.

Barletta, M. \& Saint-Paul, U. 2010. Distribution Pattern of Fish in a Mangrove Estuary. In: Ecological Studies: Mangrove Dynamic and Management in North Brazil. U. Saint-Paul and H. Schneider (Eds.). Springer Science \& Business Media, Verlag Berlin Heidelberg. pp. 172-188. 
Blaber, S.J.M. 1997. Fish and Fisheries of Tropical Estuaries Fish and Fisheries. Chapman and Hall, London.

Carpenter, K.E. \& Niem, V.H. 1999-2001. FAO Species Identification Guide for Fishery Purposes. Food and Agriculture Organization of the United Nations, Rome, Italy.

Chong, V.C. \& Sasekumar, A. 2002. Fish communities and fisheries of Sungai Johor and Sungai Pulai estuaries (Johor, Malaysia). Malayan Nature Journal, 56: 279-302.

Chong, V.C., Sasekumar, A., Leh, M.U.C. \& Cruz, R.D. 1990. The fish and prawn communities of a Malaysian mangrove system, with comparisons to adjacent mud flats and inshore waters. Estuarine, Coastal and Shelf Science, 31: 703-722.

Chong, V.C., Ng, Y.P., Hairi, B.J., Ooi, A.L., Chew, L.L., Amirah, M. \& Affendy, B.N. 2005. Update of the fishes of mangrove and coastal waters of Northeastern Langkawi. Malaysian Journal of Sciences, 24: 167-184.

Chong, V.C., Jamizan, A.R., Mohamad Yazid, Z., Rizman-Idid, Muhammad Ali, S.H. \& Natin, P. 2010. Diversity and Abundance of Fish and Invertebrates of Semerak Estuary and Adjacent Inshore Waters, Kelantan. Malaysian Journal of Science, 29: 95-110.

Clarke, K.R. 1993. Non-parametric multivariate analyses of changes in community structure. Australian Journal of Ecology, 18: 117-143.

Eddy, F.B. 2005. Ammonia in estuaries and effects on fish. Journal of Fish Biology, 67(6): 1495 1513.

Fernandes, B. \& Achuthankutty, C.T. 2010. Seasonal variation in fishery of some wetlands of the Salcete Taluka, Goa, India. Indian Journal of Marine Sciences, 39: 238-247.

Flannery, M.S., Peebles \& Montgomery. 2002. A percent of flow approach for managing reductions of freshwater inflows from unimpounded rivers to southwest Florida estuaries. Estuaries Coasts, 25: 1318-1332.

Giarrizzo, T. 2007. Importance of mangroves for fish bases for the conservation and sustainable management of mangrove ecosystems in North Brazil (Ph.D). University of Bremen.

Gillian, J.F., Fraser, D.F. \& Alkins-Koo, M. 1993. Structure of a Tropical Stream Fish Community: A Role for Biotic Interactions. Ecology, 74: 1856-1870.

Hossain, M.S., Das, N.G., Sarker, S. \& Rahaman, M.Z. 2012. Fish diversity and habitat relationship with environmental variables at Meghna river estuary, Bangladesh. The Egyptian Journal of Aquatic Research, 38: 213-226.
Jimmy, A. 2007. Species composition, distribution, and feeding guilds of fishes from Sungai Pulai Seagrass Beds (Master). University Putra Malaysia.

Kadir, S.T.S.A., Mohamad-Norizam, M., Baharim, N.B., Arai, T., Motomura, H., Husain, M.-L., Ambak, M.A. \& Ghaffar, M.A. (2019). Diversity and Abundance Fish Assemblages in the Setiu Wetlands, Terengganu, Malaysia. In: Greater Kenyir Landscapes. M.T. Abdullah, A. Mohammad, M. Nor Zalipah, and M. Safiih Lola. (Eds.). Springer Nature Switzerland AG, Switzerland. pp. 327.

Kennish, M.J. 1990. Ecology of Estuaries Volume II Biological Aspects. CRC Press Inc, Boca Raton, Florida.

Khoo, K.H. 1990. The mangrove fisheries in Matang, Perak, and Merbok, Kedah. In: Report of ASEAN Australia Cooperative Program on Marine Science Coastal Living Resources Project (Phase I). B.H.R. Othman (Eds.). Faculty of Sciences, UKM, Bangi, Malaysia.

Kiso, K. \& Mahyam, M.I. 2003. Distribution and feeding habits of juvenile and young John's snapper Lutjanus johnii in the Matang mangrove estuary, west coast of Peninsular Malaysia. Fisheries Science, 69: 563-568.

Kuo, S.R., Lin, H.J. \& Shao, K.T. 1999. Fish assemblages in the mangrove creeks of northern and southern Taiwan. Estuaries, 22: 1004-1015.

Laroche, J., Baran, E. \& Rasoanandrasana, N.B. 1997. Temporal patterns in a fish assemblage of a semiarid mangrove zone in Madagascar. Journal of Fish Biology, 51: 3-20.

Matsunuma, M., Motomura, H., Matsuura, K., Shazili, N.A.M. \& Ambak, M.A. 2011. Fishes of Terengganu-east coast of Malay Peninsula, Malaysia. National Museum of Nature and Science, University Malaysia Terengganu and Kagoshima University Museum.

Mohsin, A.K.M. \& Ambak, M.A. 1983. Freshwater fishes of Peninsular Malaysia. Universiti Pertanian Malaysia, Selangor.

Mohsin, A.K.M. \& Ambak, M.A. 1996. Marine Fishes \& Fisheries of Malaysia and Neighbouring Countries. Universiti Pertanian Malaysia Press, Selangor.

Nakabo, T. 2002. Fishes of Japan with Pictorial Keys to the Species. Tokai University Press, Kanagawa, Japan.

Othman, M. 2014. Ecological Factors Affecting Fish Diversity and Density in Sungkai Wildlife Reserve. Perak, Malaysia. 
Ramsundar, H. 2005. The distribution and abundance of wetland ichthyofauna, and exploitation of the fisheries in the Godineau Swamp, Trinidad - Case study. Revista de Biología Tropical, 53: 11-23.

Riley, J.P. \& Chester, R. 1971. Introduction to Marine Chemistry. Academic Press, United States.

Robertson, A.I. \& Duke, N.C. 1990. Mangrove fish communities in tropical Australia: spatial and temporal patterns in densities, biomass, and community structure. Marine Biology, 104: 369-379.

Sarpedonti, V. \& Chong, V.C. 2008. Abundance and distribution of Stolephorus baganensis (Hardenberg 1933) and Thyrssa kammalensis (Bleeker 1849) larvae in relation to ontogeny and environmental factors in a Malaysian estuary. Tropical Zoology, 21: 195-208.

Sasekumar, A., Chong, V.C., Lim, K.H. \& Singh, H.R. 1994. The fish community of Matang mangrove waters. In: Proceedings ThirdASEAN-Australia Symposium on Living Coastal Resources (Volume 2). S. Sudara, C.R. Wilkinson \& L.M. Chou (Eds.). Chulalongkorn University, Bangkok, Thailand. pp. 457-464.

Serafy, J.E., Faunce, C.H. \& Lorenz, J.J. 2003. Mangrove shoreline fishes of Biscayne Bay, Florida. Bulletin of Marine Science, 72: 161180.
Shukor, M.N., Samat, A., Ahmad, A.K. \& Ruziaton, J. 2008. Comparative analysis of length-weight relationship of Rasbora sumatrana relation to the physicochemical characteristic in different geographical areas in Peninsular Malaysia. Malaysian Applied Biology, 37(1): 21-29.

Sichum, S., Tantichodok, P. \& Jutagate, T. 2013. Diversity and assemblage patterns of juvenile and small-sized fishes in the nearshore habitats of the Gulf of Thailand. The Raffles Bulletin of Zoology, 61: 795-809.

Suratman, S., Mohd Tahir, N., Jusoh, S.R. \& Ariffin, M.M. 2005. Assessment of anthropogenic effects on water quality in Setiu Wetland, Terengganu (in Malay). Sains Malaysiana, 34: 87-92.

Suratman, S., Awang, M., Loh, A.L. \& Mohd Tahir, N. 2009. Water quality index study in Paka River basin, Terengganu (in Malay). Sains Malaysiana, 38: 125-131.

Suratman, S., Hussein, A.N.A.R., Latif, M.T. \& Weston, K. 2014. Reassessment of physicchemical water quality in Setiu Wetlands, Malaysia. Sains Malaysiana, 43: 1127-1131.

Suratman, S., Hussein, A.N.A.R., Tahir, N.M., Latif, M.T., Mostapa, R. \& Weston, K. 2016. Seasonal and spatial variability of selected surface water quality parameters in Setiu Wetland, Terengganu, Malaysia. Sains Malaysiana, 45(4): 551-558.

Whitney, R.J. 1942. Diurnal fluctuations of oxygen and $\mathrm{pH}$ in two small ponds and a stream. Journal of Experimental Biology, 19: 92-99. 
